\title{
Blood gas transport at high altitude
}

\author{
Michele Samaja \\ Dipartimento di Scienze e Tecnologie Biomediche \\ University of Milano, Milano, Italy
}

Address for correspondence: Michele Samaja, Dipartimento di Scienze e Tecnologie Biomediche, via Fratelli Cervi 93, I-20090 Segrate Milano, Italy, tel +39-2-26423356, fax +39-2-26423355, e-mail mis@imiucca.csi.unimi.it

Keywords: Hypoxia, acid-base balance, oxygen transport, 2,3-diphosphoglycerate

\begin{abstract}
As a model of human hypoxia, exposure to high-altitude causes a number of ventilatory, circulatory and hemopoietic adaptations. A review of literature on bloodgas transport responses to hypoxia indicates that they are influenced not only by altitude, but also by factors related to acclimatization. In addition, it appears that the need to oxygenate tissues conflicts with the need to maintain $\mathrm{H}^{+}$homeostasis. Thus, the final situation represents a compromise between the respiratory adjustment aimed at increasing blood alkalosis in order to optimize the oxygen transport system, and the metabolic readjustment aimed at re-establishing normal blood $\mathrm{pH}$. There are factors like red cell 2,3-diphosphoglycerate, a compound that decreases the hemoglobin affinity for oxygen, that can influence that balance by affecting arterial oxygen saturation through mechanisms independent of respiration.
\end{abstract}

\section{Introduction}

Exposure to high altitude is associated to a number of physiological and pathological responses. The first description of the deleterious effects of high altitude on humans seems to date back to 30 B.C., when Tseen Han Shoo so described the journey along the Silk Road in Karakorum: "The route from the Western regions to the Hindu Kush crosses the Great Headache mountain, the Little Headache mountain, [where] men's body become feverish, lose color, and are attached with headache and vomiting" [1]. Since the $19^{\text {th }}$ century, with the studies by Paul Bert, it is appreciated that altitude problems stem out from the decreased barometric pressure, hence hypoxia.

If adaptation is defined as a change that reduces the physiological strain produced by stressful aspects of the environment [2], it is either genotypic or phenotypic [3]. In the latter case, it is also termed "acclimatization" [4]. Humans can adapt to hypoxia, although less extensively than other mammals do [5], by establishing some degree of compensation at several levels [6-8]. Briefly, at ventilatory level, hypoxic stimulation of chemoreceptors causes an immediate increase of alveolar ventilation. The consequent washout of large quantities of $\mathrm{CO}_{2}$ initially reduces arterial $\mathrm{CO}_{2}$ tension $\left(\mathrm{P}_{\mathrm{a}} \mathrm{CO}_{2}{ }^{+}\right)$and

+II List of abbreviations: AMS; acute mountain sickness; BE, base excess; DPG, 2,3diphosphoglycerate; $\mathrm{Hb}$, hemoglobin; $\mathrm{OEC}, \mathrm{O}_{2}$ equilibrium curve; $\mathrm{P}_{\mathrm{a}} \mathrm{CO}_{2}$, arterial $\mathrm{CO}_{2}$ tension; $\mathrm{P}_{\mathrm{a}} \mathrm{O}_{2}$, arterial $\mathrm{O}_{2}$ tension; $\mathrm{pH}_{\mathrm{a}}$, arterial $\mathrm{pH} ; \mathrm{P}_{\mathrm{v}} \mathrm{O}_{2}$, venous $\mathrm{O}_{2}$ tension; $\mathrm{P}_{50}, \mathrm{PO}_{2}$ at 
increases arterial $\mathrm{pH}\left(\mathrm{pH}_{\mathrm{a}}\right)$. Subsequently, whereas the chemoreflexogenic hyperventilatory response remains unchanged, $\mathrm{pH}_{\mathrm{a}}$ tends to return to near normal levels as a consequence of $\mathrm{HCO}_{3}^{-}$loss through the kidney. At circulatory level, hypoxia increases circulatory efficiency by three mechanisms: (1) immediate increase in cardiac output, followed by a return to near normal levels in a few days; (2) increase of tissue capillarity; (3) increase of the red cell concentration of 2,3-diphosphoglycerate (DPG), a compound that decreases hemoglobin $(\mathrm{Hb})-\mathrm{O}_{2}$ affinity thereby enhancing $\mathrm{O}_{2}$ delivery to tissue. At hemopoietic level, hypoxia stimulates spleen and bone marrow leading to: (1) progressive increase of circulating hemoglobin over a period of several months (but the advantage of increased blood $\mathrm{O}_{2}$ capacity are set off by increased blood viscosity); (2) faster replacement of relatively "old" red blood cells by "young", fresh red blood cells with more favorable $\mathrm{O}_{2}$ transport characteristics. At metabolic level, although mitochondria and cellular oxidative machinery are slightly more plentiful in some animals native to altitude than in sea level controls, the importance of this adjustment in humans is questionable and general consensus is now against this possibility [9].

\section{Literature}

The purpose of this brief review is to analyze the mechanisms underlying the response of the gas transport system to hypoxia in resting subjects. Figure 1 shows a summary of available literature [8,10-21]. Unless otherwise stated, the figure reports blood gas transport data relative to Caucasian subjects exposed to real or simulated altitudes $>4300 \mathrm{~m}$, along with additional data referring to natives to the same or lower altitude, as well as subjects with altitude-related disorders. The relevant data dispersion is caused by the combination of the following features: (1) Difficult operating conditions in several studies performed at altitude; (2) Different duration times of altitude exposure of the subjects prior to analyses, from a few hours to several days or weeks; and (3) unaccuracies in defining either altitude or barometric pressure. Actually, the equation proposed by the International Civil Aviation Organization to derive the barometric pressure from altitude:

$$
\mathrm{P}=\mathrm{P}_{0} \mathrm{e}^{-\mathrm{Mgh}} / \mathrm{RT}
$$

where $\mathrm{P}_{0}$ is pressure at sea level, $\mathrm{M}$ is the average molecular weight of gas molecules, $\mathrm{g}$ the acceleration of gravity, and $h$ the height, provides a low guess of the real barometric pressure. On the summit of Mt.Everest, this discrepancy accounts for up to 7\% [22], which has enormous implications for gas transport [23].

Despite data dispersion, decreasing trends are uniformly observed for arterial $\mathrm{O}_{2}$ tension $\left(\mathrm{P}_{\mathrm{a}} \mathrm{O}_{2}\right)$, arterial $\mathrm{O}_{2}$ saturation $\left(\mathrm{S}_{\mathrm{a}} \mathrm{O}_{2}\right)$ and $\mathrm{P}_{\mathrm{a}} \mathrm{CO}_{2}$, whilst $\mathrm{pH}_{\mathrm{a}}$ and the blood molar ratio $[\mathrm{DPG}] /[\mathrm{Hb}]$ increase with altitude. In general, data taken under simulated altitude conditions in hypobaric chambers $[14,15]$ are within the limits of those taken under real altitude conditions, with the exception of $\mathrm{P}_{\mathrm{a}} \mathrm{O}_{2}$ and DPG. Blood $[\mathrm{Hb}]$ always increases, a common finding in all studies, but since it depends on both degree and duration of hypoxia, this variable can not be conveniently plotted as a function of altitude. Indeed, serum erhytropoietin peaks a few days after hypoxic exposure followed by progressive

which half of hemoglobin is saturated with $\mathrm{O}_{2} ; \mathrm{S}_{\mathrm{a}} \mathrm{O}_{2}$, arterial $\mathrm{O}_{2}$ saturation; $\Delta \mathrm{O}_{2(\mathrm{a}-\mathrm{v})}$, arterial-to-venous $\mathrm{O}_{2}$ gradient. 
decrease during the following weeks, leading to maintained or slightly decreasing blood [Hb] [24]. In addition, occurrence of striking differences among various populations living at high altitudes also suggests presence of genetic-related patterns [25].

In this discussion, it is convenient to set an arbitrary altitude of $\sim 4300 \mathrm{~m}$, roughly corresponding to a reduction of inspired $\mathrm{PO}_{2}$ by one-half. Indeed, this altitude is near the highest altitude to which man can be acclimatized and can live and perform work for months [6]. Severe hypoxic stress prevents establishment of permanent human settlings above $4500 \mathrm{~m}$, and induces $>50 \%$ incidence of acute altitude-related disorders in sojourners and trekkers [26]. Although it is questionable whether the process of human adaptation to hypoxia would never be considered accomplished [8], it is also useful to compare groups of subjects characterized by different degrees of adaptation. Indeed, compensatory mechanisms may exist in individuals acclimatized to lower altitudes that induce different responses during adaptation to higher altitudes. Whilst $\sim 1 \%$ of world population reside at altitudes exceeding 3300m [27], only two populations permanently reside at altitudes up to 4300-4500m. Himalayan Sherpas are known as healthy, welladapted, virtually immune from altitude-related disorders [28]. In contrast, Andean Quechuas apparently did not develop adaptation as shown from their higher erythropoietic stimulus [29]. Finally, subjects suffering from acute mountain sickness (AMS) [30] represent the case of failed acclimatization process. This failure helps to understand the gas transport system at altitude as it does not involve other possibly implicated systems as blood rheology and hence microcirculation [31].

\section{Blood gases and acid-base balance}

The $\mathrm{P}_{\mathrm{a}} \mathrm{O}_{2}$ value progressively decreases with altitude. Whilst $\mathrm{P}_{\mathrm{a}} \mathrm{O}_{2}$ in AMS subjects was always lower than that of matched controls $[16,18,21]$, the effects of acclimatization on $\mathrm{P}_{\mathrm{a}} \mathrm{O}_{2}$ are not clear. In one study, 18 days acclimatization to $4300 \mathrm{~m}$ increased $\mathrm{P}_{\mathrm{a}} \mathrm{O}_{2}$ [17]. Also, if American Indians are to be considered poorly adapted to hypoxia, then their lower $\mathrm{P}_{\mathrm{a}} \mathrm{O}_{2}$ with respect to Caucasians is not surprising [10]. However, another study failed to observe any effect of 3 weeks adaptation to $5050 \mathrm{~m}$ nor differences in $\mathrm{P}_{\mathrm{a}} \mathrm{O}_{2}$ of Sherpas and Caucasians acutely exposed to $6450 \mathrm{~m}$ [21]. The ventilatory determinants of $\mathrm{P}_{\mathrm{a}} \mathrm{O}_{2}$, i.e., the gas exchange ratio and alveolar ventilation, are outside the limits of this review, but, as originally pointed out, an adaptive reduction of alveolar-arterial $\mathrm{O}_{2}$ gradient in the course of acclimatization would represent an effective defense against hypoxia [6]. Thus, the classical, now 25-years old hypothesis, that incomplete red cell equilibration along the pulmonary capillary is crucial to determine $\mathrm{P}_{\mathrm{a}} \mathrm{O}_{2}$, appears still fully valid [32].

Graphical representation of the $\mathrm{CO}_{2}$ hydration reaction $\left(\mathrm{H}_{2} \mathrm{O}+\mathrm{CO}_{2}<=>\mathrm{H}^{+}+\mathrm{HCO}_{3}^{-}\right)$by the $\mathrm{pH}-\mathrm{HCO}_{3}^{-}$diagram (Figure 2) shows that both volatile $\left(\mathrm{CO}_{2}\right)$ and metabolic $\left(\mathrm{H}^{+}\right)$factors determine blood $\mathrm{pH}$. The changes of the former follow the buffer lines, whilst changes of the latter follow the iso- $\mathrm{PCO}_{2}$ curves. The base excess (BE, i.e., the amount of fixed $\mathrm{H}^{+}$ that would have to be added to blood to titrate it to $\mathrm{pH} 7.4$ at a $\mathrm{PCO}_{2}$ of $40 \mathrm{mmHg}$ at $37^{\circ} \mathrm{C}$ [33]) helps to assess the contribution of metabolic $\mathrm{H}^{+}$to acid-base imbalance: in the -2 to $+2 \mathrm{mEq} / 1$ range, altered $\mathrm{PCO}_{2}$ is the only contributor to acid-base imbalance; otherwise, metabolic $\mathrm{H}^{+}$is involved. In healthy humans, $\mathrm{pH}_{\mathrm{a}}$ is allowed to fluctuate within a rather narrow range (7.35-7.45). The control systems that titrate $\mathrm{pH}_{\mathrm{a}}$ to its normal value $(7.40 \pm 0.02)$ are: (1) Body fluids buffer systems, which operate within 
fractions of second after the onset of the stimuli; (2) Ventilatory response (fast, but with $50-75 \%$ effectiveness); and (3) Metabolic compensation (slow, but powerful).

In humans exposed to hypoxia, the decrease of alveolar $\mathrm{PO}_{2}$ is accompanied by decreasing alveolar $\mathrm{PCO}_{2}$ [34]. The hypothetical case of acute exposure to approximately $5000 \mathrm{~m}$ is represented in the $\mathrm{pH}_{-} \mathrm{HCO}_{3}^{-}$diagram by moving from 1 to 2 along the buffer line at $\mathrm{BE}=0 \mathrm{mEq} / \mathrm{l}$. The effect of $[\mathrm{Hb}]$ on the slope of the buffer line is here neglected. The resulting alkalinization triggers responses aimed at titrating blood $\mathrm{pH}$ back to 7.4, but since the kidney is not able to fully accomplish this task at altitude, blood remains alkaline ( 3 in the diagram). Perhaps this is due to the slowness of renal compensation that can't cope with continuous $\mathrm{CO}_{2}$ washout from the lungs, but the reasons for this lack of compliance are not yet understood. Actually, at $6300-6450 \mathrm{~m}$, when considering the increase of $[\mathrm{Hb}], \mathrm{BE}$ was $-6 \mathrm{mEq} / 1$, whereas a $\mathrm{BE}$ of -10 to $-9 \mathrm{mEq} / 1$ would have been necessary for complete metabolic compensation [13,21].

Comparative analysis of the $\mathrm{pH}-\mathrm{PCO}_{2}$ relationships in other groups of subjects helps to assess the above issues. In Sherpas, $\mathrm{P}_{\mathrm{a}} \mathrm{CO}_{2}$ is higher, and their $\mathrm{pH}_{\mathrm{a}}$ is lower than in Caucasians [21]. As BE is comparable in the two groups, one can infer that less hypoxic ventilatory drive in Sherpas [35] prevents excessive fall of $\mathrm{P}_{\mathrm{a}} \mathrm{CO}_{2}$ and rise of alkalosis. Probably, low DPG in Sherpas' blood contributes to keep high $\mathrm{S}_{\mathrm{a}} \mathrm{O}_{2}$ to a larger extent than hyperventilation does in Caucasians. On the other hand, the high $\mathrm{pH}_{\mathrm{a}}$ value estimated on a Mt.Everest summiter [13] is probably the consequence of extreme hyperventilation that could have been beneficial for blood $\mathrm{O}_{2}$ loading. Indeed, this subject had an extremely powerful ventilatory drive due to exercise and the need to take off his oxygen mask 10 minutes before sampling [36]. Note also the steepness of the $\mathrm{pH}-\mathrm{PCO}_{2}$ relationship at low $\mathrm{PCO}_{2}$ values, which causes powerful increases of alkalosis, particularly so under hypocapnic conditions [37]. At lower altitudes, subjects who are characterized by altitude-related conditions also develop high $\mathrm{pH}_{\mathrm{a}^{\prime}}$ likely secondary to extreme hyperventilation and nearly uncompensated respiratory alkalosis.

\section{The oxygen equilibrium curve}

The main factors that influence the $\mathrm{Hb}-\mathrm{O}_{2}$ equilibrium curve $(\mathrm{OEC})$ are $\mathrm{pH}, \mathrm{PCO}_{2}$ and the $[\mathrm{DPG}] /[\mathrm{Hb}]$ ratio. Here, $\mathrm{Hb}$ fenotype, temperature, and the level of carbonmonoxy$\mathrm{Hb}$ are irrelevant. Several studies in the past have already addressed the question on how altitude alters $\mathrm{OEC}$ and hence $\mathrm{P}_{50}$, i.e., the $\mathrm{PO}_{2}$ at which $\mathrm{Hb}$ saturation for $\mathrm{O}_{2}$ is $50 \%$ $[5,6]$.

Red cell DPG is critical during hypoxia. A glycolytic intermediate occurring in all tissues, only in the red cell DPG reachs sizeable concentrations. Hypoxia further increases DPG by three mechanisms: (1) Preferential DPG binding to deoxygenated $\mathrm{Hb}$ [38] and high levels of this $\mathrm{Hb}$ during hypoxia decrease free DPG levels thereby enhancing synthesis [39]; (2) Alkalosis associated with hypoxia stimulates DPG mutase and inhibits DPGphosphatase [39]; (3) Hemopoietic stimulation increases the fraction of "young", DPGrich red cells $[19,24]$. As a result of these synergisms, the [DPG]/[Hb] ratio always increases with hypoxia, but Figure 1 shows that the dispersion of DPG data is much higher than that observed for the other parameters. Possibly, the above mentioned variability factors are complicated by additional problems as the time duration of hypoxia, the degree of effort over the days or weeks before sampling, and technical difficulties related to blood storage, extraction and enzymatic analysis with 
spectrophotometric methods. Indeed, since DPG is a rather unstable metabolite, the blood sample should be obtained in suitable anticoagulant, and stored for no more than a few hours at ice temperature before enzymatic analysis.

Increased DPG shifts the OEC to the right in antagonism with alkalosis. An algorithm [40] allows to assess the effects of those factors on the OEC even under the extreme conditions of $\mathrm{pH}, \mathrm{PCO}_{2}$ and $[\mathrm{DPG}] /[\mathrm{Hb}]$ found at high altitude: the discrepancy between measured $\mathrm{P}_{50}$ and that calculated from the algorithm accounts for 0.2-0.4 $\mathrm{mmHg}$ [13]. In Caucasians at $6300 \mathrm{~m}$, the $\mathrm{P}_{50}$ value is higher than at sea level $(29.8 \pm 2.2$ $\mathrm{mmHg}$ [13] vs $27.5 \mathrm{mmHg}$ [41]). Thus, the rightward shift caused by DPG appears stronger than the leftward displacement caused by alkalosis. As a matter of fact, an increase of the [DPG]/[Hb] molar ratio from 0.80 (sea level) to 1.36 (6450m [21]) would have required an increase of $\mathrm{pH}_{\mathrm{a}}$ from 7.40 to 7.56 for complete compensation, i.e., much stronger alkalosis than actually measured. On the other hand, should alkalosis be fully compensated by metabolic acidosis, thus offsetting the effect of $\mathrm{pH}$, then $\mathrm{P}_{50}$ would have been $33 \mathrm{mmHg}$.

There are very few data on DPG in altitude natives dwelling at altitudes $>4300 \mathrm{~m}$, and apparently no data at all for subjects with altitude-related disorders. However, in Sherpas, the $[\mathrm{DPG}] /[\mathrm{Hb}]$ ratio should be less than in Caucasians. Although at $3800 \mathrm{~m}$ the $[\mathrm{DPG}] /[\mathrm{Hb}]$ ratio was the same in the two groups $[29,42]$, at $5050 \mathrm{~m}$ it was definitely lower in Sherpas than in Caucasians (1.04 \pm 0.04 vs $1.28 \pm 0.05$, respectively [24]). It is likely that such trend does continue even at higher altitudes. In addition, when the $[\mathrm{DPG}] /[\mathrm{Hb}]$ ratio is calculated by the algorithm from actual Sherpas $\mathrm{P}_{\mathrm{a}} \mathrm{O}_{2}, \mathrm{P}_{\mathrm{a}} \mathrm{CO}_{2}, \mathrm{pH}_{\mathrm{a}}$ and $\mathrm{S}_{\mathrm{a}} \mathrm{O}_{2}$, it is estimated at $\sim 1.2[21]$.

\section{Tuning of blood $\mathrm{O}_{2}$ transport}

Blood OEC shifts are important to optimize the blood $-\mathrm{O}_{2}$ transport. The physiological relevance of the OEC sigmoid shape is to maintain high arterial-to-venous $\mathrm{O}_{2}$ gradient $\left(\Delta \mathrm{O}_{2(\mathrm{a}-\mathrm{v})}\right)$ at high venous $\mathrm{PO}_{2}\left(\mathrm{P}_{\mathrm{v}} \mathrm{O}_{2}\right)$. High $\Delta \mathrm{O}_{2(\mathrm{a}-\mathrm{v})}$ is favourable as, at the same work load, it either decreases cardiac work or increases the $\mathrm{O}_{2}$ transport [43]. At sea level, assuming constant $\mathrm{P}_{\mathrm{a}} \mathrm{O}_{2}$ and $\mathrm{P}_{\mathrm{v}} \mathrm{O}_{2}$ levels, rightward shifts of the OEC increase $\Delta \mathrm{O}_{2(\mathrm{a}-\mathrm{v})}$ (Figure 3a) because the venous point is located on the steep portion of the OEC. Therefore, small $\mathrm{P}_{50}$ increases reflect into considerable increases of $\Delta \mathrm{O}_{2(\mathrm{a}-\mathrm{v})}$. Although this situation apparently holds for moderate hypoxia (Figure 3b), it is reversed under severe hypoxia conditions, where the arterial point lies in the steep portion of the OEC (Figure 3c). Under this condition, the same $\mathrm{P}_{50}$ increase as in Figure $3 \mathrm{a}$ reflects in considerable decrease of $\Delta \mathrm{O}_{2(\mathrm{a}-\mathrm{v})}$. In theory, the threshold altitude above which a rightward shift of the OEC should be regarded as a maladaptive response is near 5400m [44]. Thus, respiratory alkalosis is favorable at extreme altitude: at $6450 \mathrm{~m}$, alkalosis increases $\mathrm{S}_{\mathrm{a}} \mathrm{O}_{2}$ by at least $5 \%$ with respect to an hypothetical non-alkalotic condition [21]. At $8848 \mathrm{~m}$, the extreme alkalosis inferred in a Mt.Everest summiter should have allowed this subject to maintain essentially same $\mathrm{S}_{\mathrm{a}} \mathrm{O}_{2}$ as that measured at a much lower $(2500 \mathrm{~m})$ altitude [13]. It is therefore evident how the mechanism triggered by alkalosis maintains $\Delta \mathrm{O}_{2(\mathrm{a}-\mathrm{v})}$ despite low $\mathrm{P}_{\mathrm{a}} \mathrm{O}_{2}$, thereby implying greater efficiency and lower load to the circulation. Interestingly, theoretical considerations based on quite different principles, i.e., diffusion limitations at the alveolar-capillary interface, point to the same conclusion: right shifts of the OEC are favourable at sea level or moderate hypoxia, but not so at very high altitude [45]. 
Prolonged alkalosis, however, is not compatible with normal body function as it is widely known to impair the central nervous system. Indeed, there appears to be a trend towards less alkalosis with acclimatization: acclimatized subjects develop less alkalosis at the same altitude, and AMS subjects are frankly alkalotic. Although it is not clear whether altitude-related disorders stem from alkalosis or if the reverse is true, alkalosis remains sustained even in subjects who do not experience AMS symptoms, but the reasons for which alkalosis is deleterious at sea level, but is relatively well tolerated at extreme altitude, are unknown. As a matter of fact, the most important action of a drug used to fight the effect of AMS, i.e., acetozolamide, is to lower $\mathrm{pH}_{\mathrm{a}}$ by inhibiting the enzyme carbonic anhydrase [27].

\section{Conclusion}

Analysis of the response of the blood-gas transport system to hypoxia indicates that, in resting subjects, the need to oxygenate tissues conflicts with the need to maintain $\mathrm{H}^{+}$ homeostasis. In other words, at high altitude the cost of meeting tissue requirements for $\mathrm{O}_{2}$ is competitive with other body functions, that may become progressively impaired by alkalosis. The final situation represents a compromise between the respiratory stimulus, which is aimed at increasing blood alkalosis in order to optimize the $\mathrm{O}_{2}$ tranport system, and the metabolic adjustment, which is aimed at re-establishing normal blood $\mathrm{pH}$. Factors like the $[\mathrm{DPG}] /[\mathrm{Hb}]$ ratio influence that balance by affecting $\mathrm{S}_{\mathrm{a}} \mathrm{O}_{2}$ through mechanisms independent of respiration. Although metabolic and ventilatory responses to exercise in moderate hypoxia are not subjected to genetic influences [46], their role in determining the responses of the gas transport system to extreme hypoxia is still to be evaluated.

\section{References}

1 Wylie A: Notes on the Western regions. J Roy Anthropol Inst 1881;10:36-38.

2 Bligh J, Johnson KG: Glossary of terms for thermal physiology. J Appl Physiol 1973;35:941-961.

3 Hochachka PW, Matheson GO, Parkhouse WS, Sumar-Kalinovski J, Stanley C, Monge CC, McKenzie DC, Merkt J, Man PSF, Jones R, Allen PS: Paths of oxygen from atmosphere to mitochondria in andean natives: adaptable vs constrained components; in Sutton JR, Coates G, Remmers JE (eds): Hypoxia: The Adaptations. Toronto, Decker, 1990, pp 72-87.

4 Smith MV, Hazucha MJ, Benignus VA, Bromberg PA: Effect of regional circulation patterns on observed HbCO level. J Appl Physiol 1994;77:1659-1665.

5 Monge CC, Leon-Velarde F: Physiological adaptation to high altitude: oxygen transport in mammals and birds. Physiol Rev 1991;71:1135-1172.

6 Cerretelli P: Gas exchange at high altitude; in Pulmonary Gas Exchange. Academic Press Inc., 1980, pp 97-147.

7 Cerretelli P, Hoppeler H: Morphologic and metabolic response to chronic hypoxia: the muscle system; in Fregly MJ, Blatteis CM (eds): Handbook of Physiology: Section 4: Environmental Physiology, Volume II. New York, Oxford, American Physiological Society, 1996, pp 1155-1181. 
8 Winslow RM, Monge CC: Hypoxia, polycythemia, and chronic mountain sickness. Baltimore and London: Johns Hopkins University Press, 1987;

9 Kayser B, Hoppeler H, Claassen H, Cerretelli P: Muscle structure and performance capacity of Himalayan Sherpas. J Appl Physiol 1991;70:1938-1942.

10 Barcroft J, Binger CA, Bock AV, Doggart JH, Forbes HS, Harrop G, Meakins JC, Redfield AC: Observations upon the effect of high altitude on the physiological processes of human body, carried out in the Peruvian Andes, chiefly at Cerro de Pasco. Philos Trans Roy Soc Lond Biol Sci 1923;211:351-454.

11 Cerretelli P: Limiting factors to oxygen transport on Mount Everest. J Appl Physiol 1976;40:658-667.

12 Birmingham Medical Research Ex[editionary Society Mountain Sickness Study Group: Acetazolamide in control of acute mountain sickness. Lancet 1981;180-183.

13 Winslow RM, Samaja M, West JB: Red cell function at extreme altitudes on Mount Everest. J Appl Physiol 1984;56:109-116.

14 Sutton JR, Reeves JT, Wagner PD, Groves BM, Cymerman A, Malconian MK, Rock PB, Young PM, Walter SD, Houston CS: Operation Everest II: oxygen transport during exercise at extreme simulated altitude. J Appl Physiol 1988;64:1309-1321.

15 Jelicks LA, Gupta RK: ${ }^{31} \mathrm{P}-\mathrm{NMR}$ of high energy phosphates in perfused rat heart during metabolic acidosis. Am J Physiol 1992;263:H903-H909.

16 Oelz O, Maggiorini M, Ritter M, Waber U, Jenni R, Vock P, Bärtsch P: Nifedipine for high altitude pulmonary oedema. Lancet 1989;1241-1244.

17 Bender PR, Groves BM, McCullough RE, McCullough RG, Trad L, Young AJ, Cymerman A, Reeves JT: Decreased exercise muscle lactate release after high altitude acclimatization. J Appl Physiol 1989;67:1456-1462.

18 Bärtsch P, Baumgartner RW, Waber U, Maggiorini M, Oelz O: Comparison of carbondioxide enriched, oxygen-enriched, and normal air in treatment of acute mountain sickness. Lancet 1990;336:772-775.

19 Mairbaurl H, Schobersberger W, Oelz O, Bärtsch P, Eckardt KU, Bauer C: Unchanged in vivo $p_{50}$ at high altitude despite decreased erythrocyte age and elevated 2,3diphosphoglycerate. J Appl Physiol 1990;68:1186-1194.

20 Kayser B, Ferretti G, Grassi B, Binzoni T, Cerretelli P: Maximal lactic capacity at altitude: effect of bicarbonate loading. J Appl Physiol 1993;75:1070-1074.

21 Samaja M, Mariani C, Prestini A, Cerretelli P: Acid-base balance and $\mathrm{O}_{2}$ transport at high altitude. Acta Physiol Scand 1997;(in press)

22 West JB, Lahiri S, Maret KH, peters RM, Pizzo CJ: Barometric pressure at extreme altitudes on Mt. Everest: physiological significance. J Appl Physiol 1983;54:1188-1194.

23 West JB, Wagner PD: Predicted gas exchange on the summit of Mt. Everest. Respir Physiol 1980;42:1-16.

24 Samaja M, Brenna L, Allibardi S, Cerretelli P: Human red cell aging at $5050 \mathrm{~m}$ altitude: a role during adaptation to hypoxia. J Appl Physiol 1993;75:1696-1701. 
25 Beall CM, Brittenham GM, Macuaga F, Barragan M: Variation in hemoglobin concentration among samples of high-altitude natives in the Andes and the Himalayas. Am J Hum Biol 1990;2:639-651.

26 Hackett PH, Rennie D, Levine HD: The incidence, importance and prophylaxis of acute mountain sickness. Lancet 1976;1149-1155.

27 Bradwell AR, Dykes PW, Coote JH: Effect of acetazolamide on exercise at altitude. Sports Med 1987;4:157-163.

28 Wabnig D: HAPE and HACE in a Sherpa? A case report. News Intern Soc Mount Med 1994;4:3-4.

29 Winslow RM, Chapman KH, Gibson CC, Samaja M, Monge CC, Goldwasser E, Sherpa M, Blume FD: Different hematologic responses to hypoxia in Sherpas and Quechua Indians. J Appl Physiol 1989;66:1561-1569.

30 Ferrazzini G, Maggiorini M, Kriemler S, Bärtsch P, Oelz O: Successful treatment of acute mountain sickness with dexamethasone. Br Med J 1987;294:1380-1382.

31 Reinhart WH, Kayser B, Singh A, Waber U, Oelz O, Bärtsch P: Blood rheology in acute mountain sickness and high altitude pulmonary edema. J Appl Physiol 1991;71:934-938.

32 Wagner PD, West JB: Effects of diffusion impairments on $\mathrm{O}_{2}$ and $\mathrm{CO}_{2}$ time courses pulmonary capillaries. J Appl Physiol 1972;33:62-71.

33 Siggaard-Andersen O: An acid-base chart for arterial blood with normal and pathophysiological reference areas. Scand J Clin Lab Invest 1971;27:239-245.

34 Rahn H, Otis AB: Man's respiratory response during and after acclimatization to high altitude. Am J Physiol 1949;157:445-462.

35 Lahiri S, Edelman NH, Cherniack NS, Fishman AP: Blunted hypoxic drive to ventilation in subjects with life-long hypoxemia. Fed Proc 1969;28:1289-1295.

36 West JB, Hackett PH, Maret KH, Milledge JS, peters RM, Pizzo CJ, Winslow RM: Pulmonary gas exchange on the summit of Mount Everest. J Appl Physiol 1983;55:678687.

37 Siggaard-Andersen O: The Acid-Base Status of Blood. Copenhagen: Munksgaard, 1974;

38 Benesch R, Benesch RE: The effect of organic phosphates from the human erythrocyte on the allosteric properties of hemoglobin. Biochem Biophys Res Comm 1967;26:162-167.

39 Duhm J, Gerlach E: On the mechanism of the hypoxia-induced increase of 2,3diphosphoglycerate in erythrocytes. Pflug Arch 1971;326:254-269.

40 Winslow RM, Samaja M, Winslow NJ, Rossi Bernardi L, Shrager RI: Simulation of continuous blood $\mathrm{O}_{2}$ equilibrium curve over the physiologic $\mathrm{pH}$, DPG and $\mathrm{pCO}_{2}$ range. J Appl Physiol 1983;54:524-529.

41 Samaja M, Mosca A, Luzzana M, Rossi Bernardi L, Winslow RM: Equations and nomogram for the relationship of human blood $\mathrm{p}_{50}$ to 2,3-diphosphoglycerate, $\mathrm{CO}_{2}$, and $\mathrm{H}^{+}$. Clin Chem 1981;27:1856-1861.

42 Samaja M, Veicsteinas A, Cerretelli P: Oxygen affinity of blood in altitude Sherpas. J Appl Physiol 1979;47:337-341. 
43 Martin JL, Duvelleroy M, Teisserie B, Duruble M: Effect of an increase in $\mathrm{HbO} 2$ affinity on the calculated capillary recruitment of an isolated rat heart. Pflug Arch 1979;382:57-61.

44 Samaja M, di Prampero PE, Cerretelli P: The role of 2,3-DPG in the oxygen transport at altitude. Respir Physiol 1986;64:191-202.

45 Bencowitz HZ, Wagner PD, West JB: Effect of change of $\mathrm{P}_{50}$ on exercise at high altitude: a theoretical study. J Appl Physiol 1982;53:1487-1495.

46 Kayser B, Marconi C, Amatya T, Basnyat B, Colombini A, Broers B, Cerretelli P: The metabolic and ventilatory response to exercise in Tibetans born at low altitude. Respir Physiol 1994;98:15-26.

\section{Legends to figures}

Figure 1. Literature data of gas transport parameters at altitude $>4300 \mathrm{~m}$ in resting subjects. Unless otherwise stated, data refer to Caucasian subjects exposed to altitude. The curves represent the best fit obtained using only these data. SD bars are omitted for clarity.

Figure 2. $\mathrm{pH}$-bicarbonate diagram representing the situation at sea level (1), after the respiratory response to acute exposure to approximately $5000 \mathrm{~m} \mathrm{(2),} \mathrm{and} \mathrm{after} \mathrm{partial}$ metabolic readjustment (3). The long-dashed lines represent the buffer lines at $[\mathrm{Hb}]=15$ $\mathrm{g} / \mathrm{dl}$.

Figure 3. Effects of a rightward shift of the $\mathrm{O}_{2}$ equilibrium curve $\left(\sim 6 \mathrm{mmHg} \mathrm{P}_{50}\right.$ corresponding to an increase of the $[\mathrm{DPG}] /[\mathrm{Hb}]$ ratio by $0.2 \mathrm{~mole} / \mathrm{mole})$ on the arterialto-venous $\mathrm{O}_{2}$ difference $\left(\Delta \mathrm{O}_{2}\right)$. At sea level ( $\left.3 a\right)$ and at moderate hypoxia (3b), the shift increases $\Delta \mathrm{O}_{2}$, whilst this trend is reversed during severe hypoxia (3c). Further explanations in the text. 


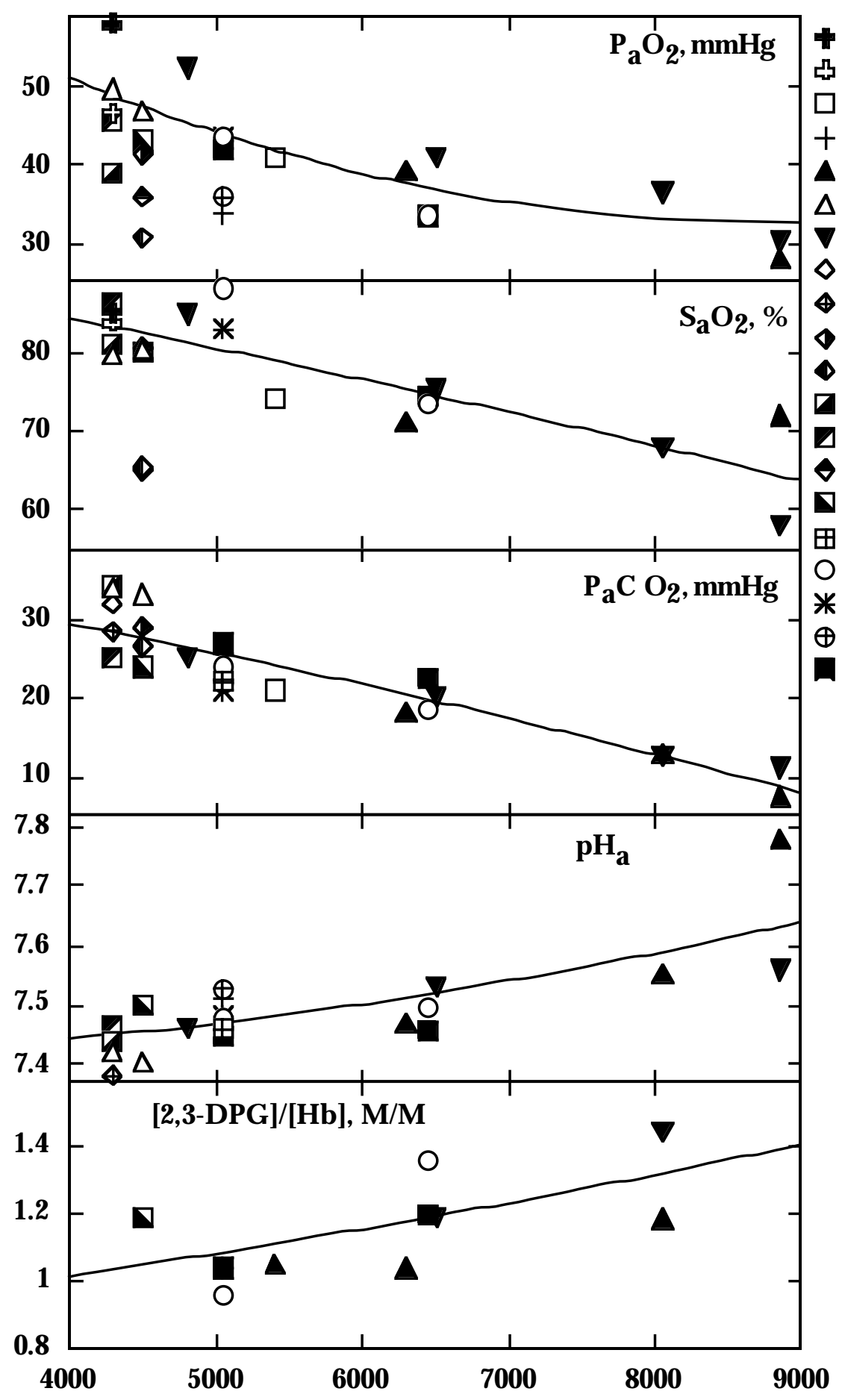

Barcroft 1923

Peruvians

Cerretelli 1976

Birmingham 1981

Winslow 1984

Winslow 1987 Peruvians

Sutton 1988 Simulated

Maclellan 1988 Simulated Acetozolamide

Oelz 1989

AMS

Bender 1989

after 18 days

Bartsch 1990 AMS

Mairbaurl 1990

Kayser 1993

Samaja 1997

after 3 weeks

AMS

Sherpas

Altitude, m 


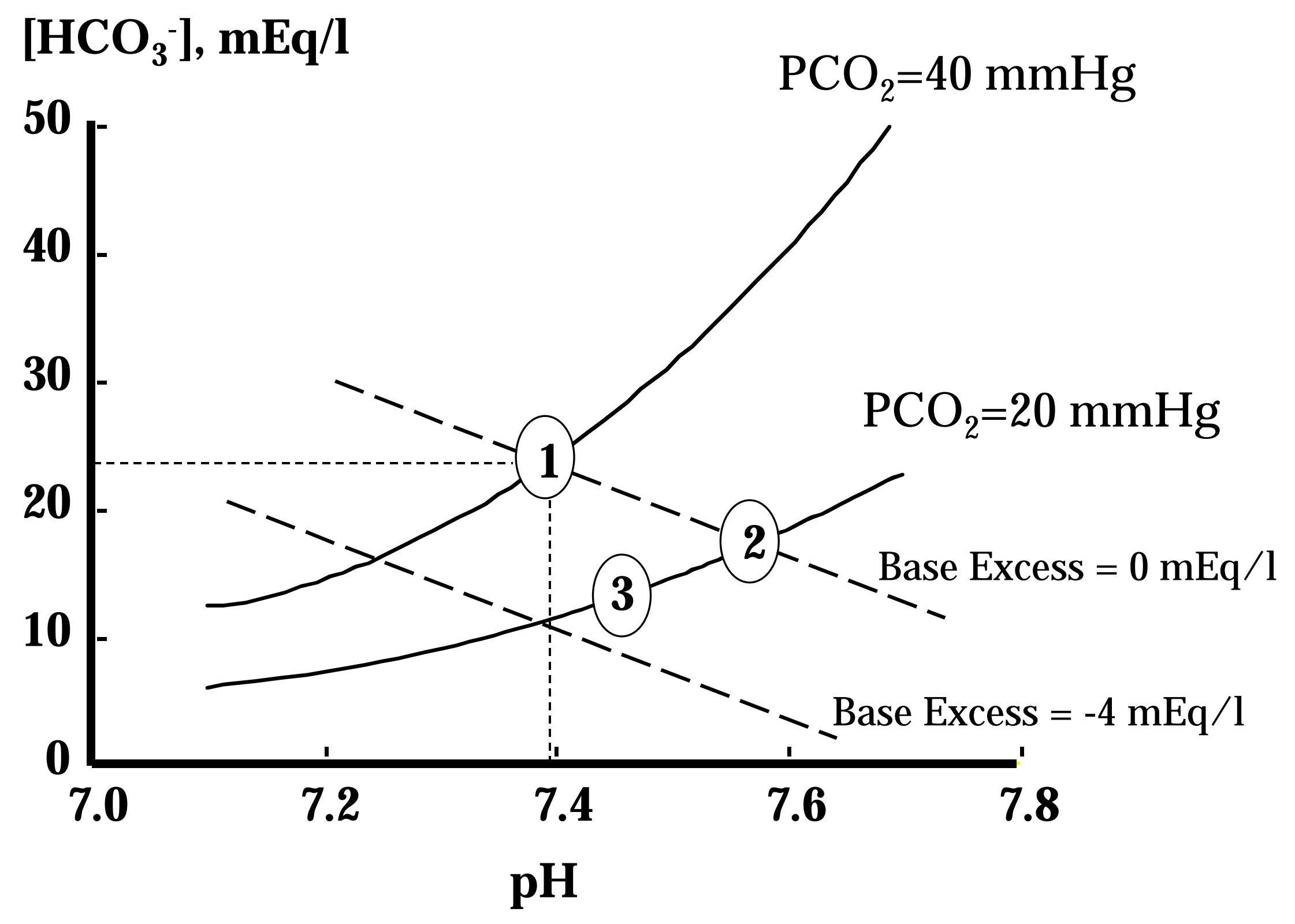




\section{Sea level}

Arterial point

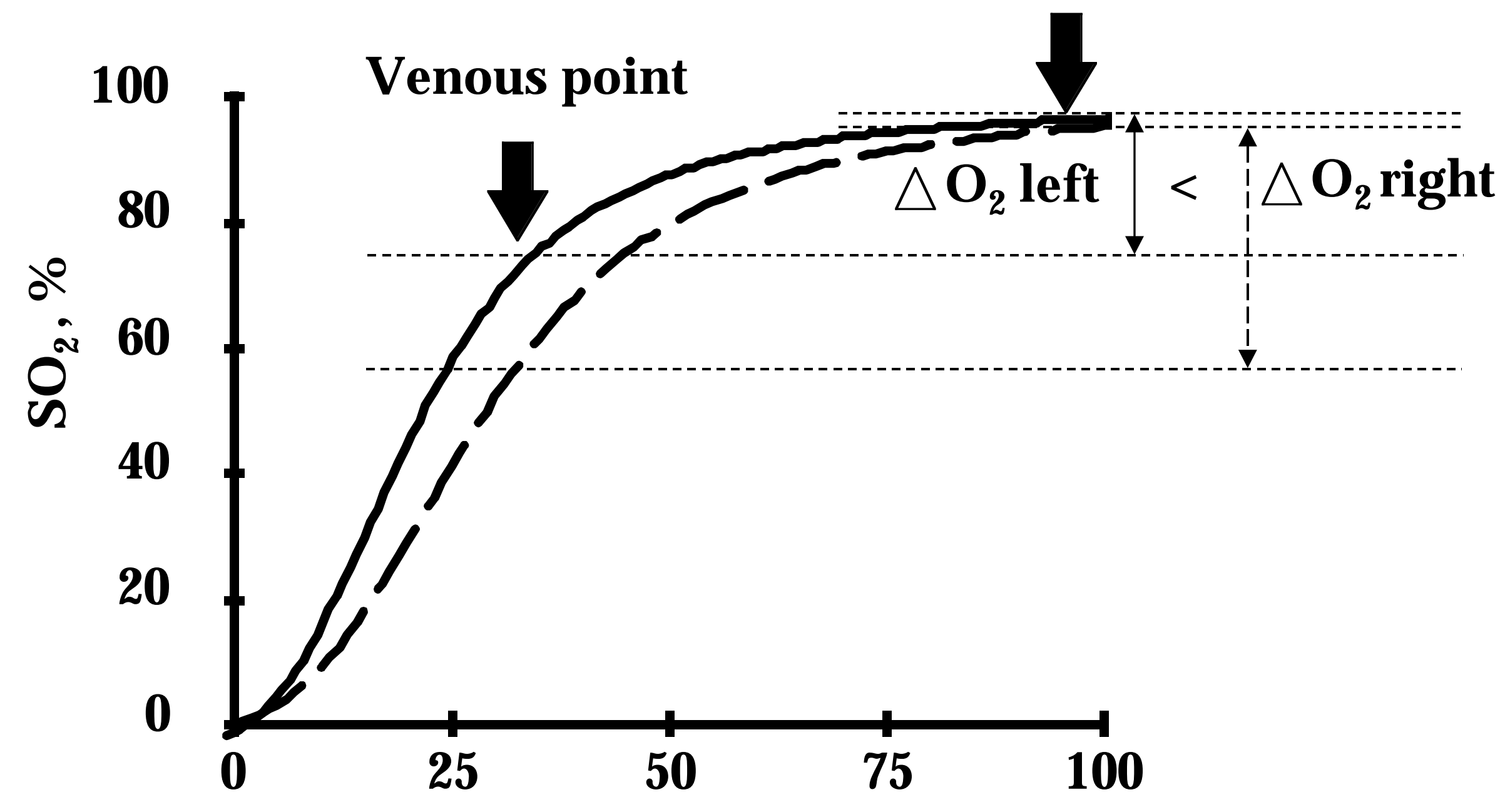

$\mathrm{PO}_{2}, \mathrm{mmHg}$ 


\section{Arterial point}

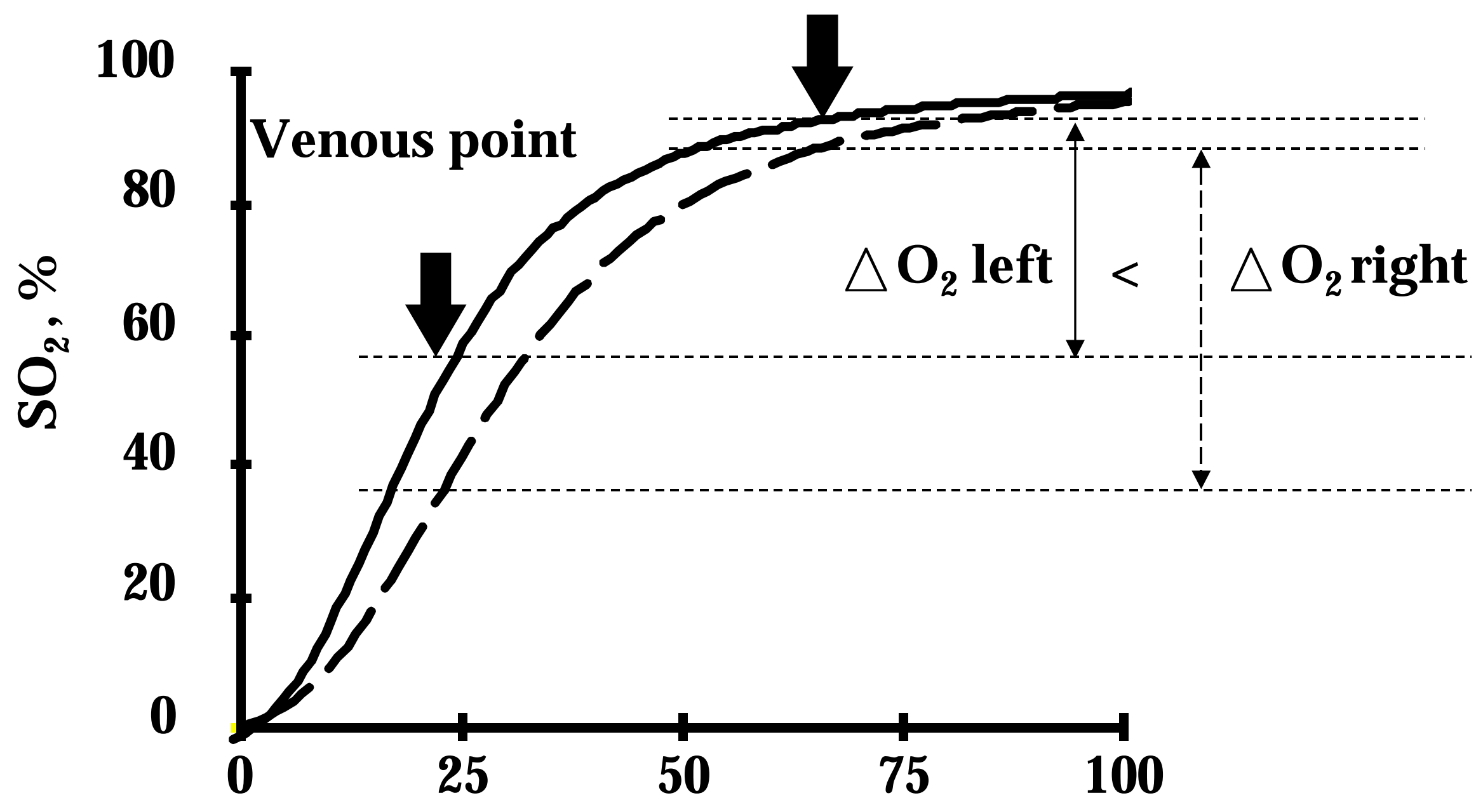

$\mathrm{PO}_{2}, \mathrm{mmHg}$ 


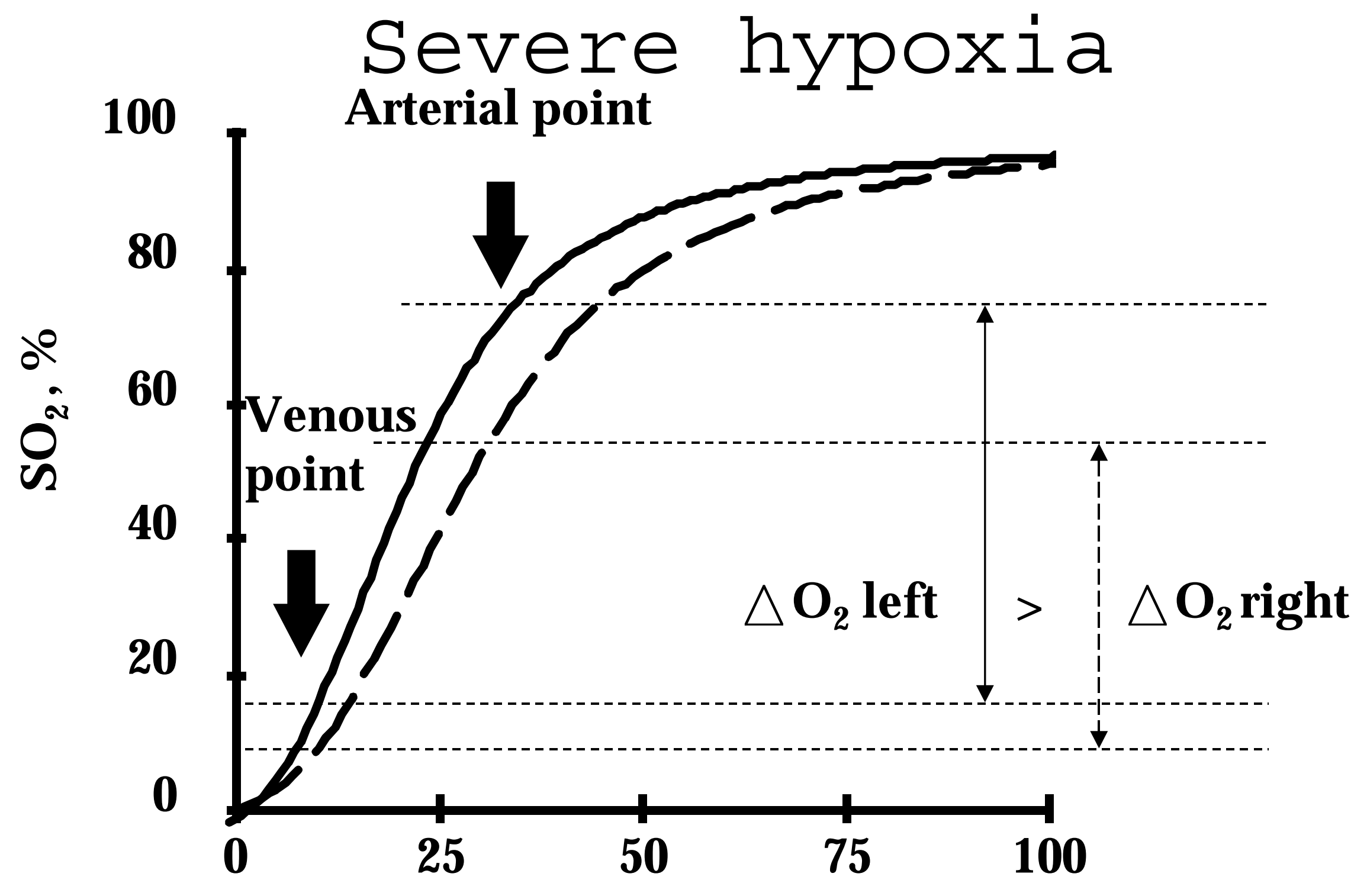

$\mathrm{PO}_{2}, \mathrm{mmHg}$ 